\title{
FLYPAPER EFFECT PADA UNCONDITIONAL GRANT
}

\author{
Irham Iskandar \\ Fakultas Ekonomi Universitas Padjadjaran Bandung \\ Jalan Dipati Ukur No.35 Bandung 40132 Telepon. (022) 2503271, Fax (022) 2509055 \\ E-mail: irhamis@yahoo.com
}

\section{Diterima 10 November 2011 / Disetujui 10 Maret 2012}

\begin{abstract}
This research is intended to know the influence of unconditional grants, local revenue, and GRDP to local expenditure and to detect the possibility of flypaper effect occurrences at local expenditure in West Java province. Population in this research is West Java Province and the sample consisted of 13 regency and 6 municipality. Estimates conducted by the panel regression using eviews program. The results of this research, the first show that unconditional grants significant and have positive relationships to local expenditure, local revenue has a significant and a positive relationship to local expenditure, GRDP has a significant and a negative relationship to the local expenditure. Second, the value of the coefficient of local revenue is greater than unconditional grants and both are significant. It indicates no occurrence of flypaper effect in West Java Province.
\end{abstract}

Keywords: flypaper effect, local revenue, local expenditure, unconditional grants

\begin{abstract}
Abstrak: Penelitian ini bertujuan mengetahui pengaruh unconditional grants, pendapatan asli daerah, dan PDRB terhadap belanja daerah dan mengetahui kemungkinan terjadinya flypaper effect pada belanja daerah di provinsi Jawa Barat. Populasi dalam penelitian ini adalah provinsi Jawa Barat dan sampelnya terdiri dari 13 kabupaten dan 6 kota. Estimasi dilakukan dengan panel regresi dengan menggunakan program eviews. Hasil dari penelitian ini, pertama menunjukkan bahwa unconditional grants berpengaruh signifikan dan mempunyai hubungan yang positif terhadap belanja daerah, pendapatan asli daerah berpengaruh signifikan dan mempunyai hubungan yang positif terhadap belanja daerah, PDRB berpengaruh signifikan dan mempunyai hubungan yang negatif terhadap belanja daerah. Kedua, nilai koefisien pendapatan daerah lebih besar dari unconditional grants dan keduanya signifikan. Ini menunjukkan tidak terjadinya flypaper effect di provinsi Jawa Barat.
\end{abstract}

Kata kunci : flypaper effect, PDRB, pendapatan daerah, belanja daerah, unconditional grants

\section{PENDAHULUAN}

Transfer antarpemerintah merupakan fenomena umum yang terjadi di semua negara di dunia terlepas dari sistem pemerintahannya dan bahkan sudah menjadi ciri yang paling menonjol dari hubungan keuangan antara pusat dan daerah (Kuncoro, 2004). Tujuan utama implementasi transfer adalah untuk mengatasi masalah eksternalitas, mengoreksi ketidakseimbangan vertikal, pemerataan fiskal antardaerah (horizontal equity) dan mencapai tujuan pembangunan tertentu (Kuncoro, 2007).
Sebelum era baru desentralisasi fiskal digulirkan pada tahun 2001, setiap daerah tingkat I dan tingkat II memiliki dua jenis penerimaan guna membiayai pengeluaran mereka yaitu pendapatan asli daerah dan dana yang ditransfer oleh pemerintah pusat (Alfirman, 2003). Krisis politik dan ekonomi telah memicu pemerintah daerah untuk mengambil peran dan tanggung jawab yang lebih besar dalam mengatur urusan daerahnya masing-masing (Wibowo, 2008). Fitrani et.al, (2005) mengungkapkan bahwa menyusul lengsernya Presiden Soeharto, terdapat tekanan untuk mereformasi setiap ke- 
bijakan yang bernuansa korupsi, kolusi dan nepotisme. Salah satu contoh kebijakan yang dimaksud adalah beberapa daerah yang mempunyai sumber daya alam berlimpah namun memperoleh bagi hasil pendapatan yang tidak fair dari pemerintah pusat (Tadjoeddin et al, 2001).

Selanjutnya, pada tahun 1999 pemerintahan Habibie meluncurkan dua produk hukum fenomenal yaitu UU No. 22 Tahun 1999 tentang Pemerintah Daerah dan UU No. 25 Tahun 1999 tentang Perimbangan Keuangan antara Pemerintah Pusat dan Daerah. Dua produk legislasi ini disusun untuk menciptakan otonomi antar daerah dan mendorong sistem pemerintahan yang lebih demokratis, sehingga dengan paradigma desentralisasi fiskal yang baru diharapkan provinsi dan kabupaten/kota berperan mengambil alih semua peran pemerintah pusat kecuali lima hal yaitu pertahanan dan keamanan, kebijakan luar negeri, peradilan, kebijakan ekonomi makro dan perencanaan nasional (Fane, 2003).

Sejak tahun anggaran 2001, pemerintah telah menerapkan UU No. 25 Tahun 1999 tentang Perimbangan Keuangan antara Pemerintah Pusat dan Daerah. Undang-undang tersebut, membawa Indonesia memasuki era baru dalam desentralisasi di bidang fiskal (fiscal decentralization atau fiscal federalism). Dampaknya terjadi perubahan struktural, di mana pada era sebelumnya pengelolaan keuangan daerah dilakukan secara sentralistik kemudian berubah menjadi desentralisasi. Tujuan umum dari perubahan tersebut adalah untuk membentuk dan membangun sistem publik yang dapat menyediakan barang dan jasa publik lokal yang semakin efektif dan efisien, dengan tetap menjaga stabilitas makroekonomi. Hal ini akan berwujud dalam bentuk pelimpahan kewenangan kepada tingkat pemerintahan untuk melakukan pembelanjaan, kewenangan untuk memungut pajak, dan adanya bantuan dalam bentuk transfer dari pemerintah pusat kepada daerah.

Seiring dengan proses pembaruan terhadap isu otonomi dan desentralisasi, pemerintah telah melakukan revisi atas UU No. 25 Tahun 1999 tentang Perimbangan Keuangan antara Pemerintah Pusat dengan Pemerintahan Daerah menjadi UU No. 33 Tahun 2004. Menurut undang-undang tersebut, sumber-sumber pendanaan pelaksanaan pemerintah daerah terdiri atas pendapatan asli daerah, dana perimbangan, dan lain-lain pendapatan yang sah. Pendapatan asli daerah terdiri dari komponen pajak daerah, retribusi daerah, hasil pengolahan kekayaan daerah yang dipisahkan, dan lain-lain pendapatan asli daerah yang sah. Dana perimbangan merupakan pendanaan daerah yang bersumber dari APBN yang terdiri atas Dana Bagi Hasil (DBH), Dana Alokasi Umum (DAU), Dana Alokasi Khusus (DAK). Secara umum Dana Bagi Hasil (DBH) dan Dana Alokasi Umum (DAU) digolongkan ke dalam bentuk unconditional transfer atau biasa disebut dengan transfer tak bersyarat, sedangkan Dana Alokasi Khusus (DAK) digolongkan ke dalam bentuk conditional transfer atau biasa disebut dengan transfer bersyarat (Brojonegoro dan Vazquez, 2002).

Kemampuan fiskal merupakan isu penting dan strategis, karena di masa mendatang pemerintah daerah diharapkan dapat mengurangi bahkan melepaskan ketergantungannya secara finansial kepada pemerintah pusat. Namun demikian, Wibowo (2008) berpendapat bahwa desentralisasi fiskal versi orde reformasi memunculkan banyak daerah yang mempunyai tanggung jawab besar namun tidak diiringi dengan kapasitas fiskal yang memadai. Senada dengan hal tersebut, Brodjonegoro (2001) menyatakan bahwa kendati daerah memperoleh dana perimbangan yang lebih besar, namun hal ini dibarengi dengan merosotnya jumlah penerimaan asli daerah dan kemampuan pengumpulan pajak lokal. Akibatnya dari tahun ke tahun pemerintah daerah selalu menuntut transfer yang lebih besar lagi dari pusat, bukannya mengeksplorasi basis pajak lokal secara optimal (Kuncoro, 2007). Keadaan tersebut juga ditemui pada kasus pemerintah daerah kota dan kabupaten di Indonesia. Data menunjukkan proporsi Pendapatan Asli Daerah (PAD) hanya mampu membiayai belanja pemerintah daerah paling tinggi sebesar 20 persen.

Dominannya peran transfer relatif terhadap pendapatan asli daerah dalam membiayai belanja pemerintah daerah sebenarnya tidak 
memberikan panduan yang baik bagi pemerintahan terhadap aliran transfer itu sendiri. Buktibukti empiris secara internasional menunjukkan bahwa tingginya ketergantungan pada transfer ternyata berhubungan negatif dengan hasil pemerintahannya (Mello dan Barenstrein, 2001). Hal ini berarti pemerintah daerah akan lebih berhati-hati dalam menggunakan dana yang digali dari masyarakat sendiri daripada dana transfer (grant) yang diterima dari pusat.

Fakta diatas secara umum memperlihatkan bahwa perilaku fiskal pemerintah daerah dalam merespon transfer dari pemerintah pusat menjadi perhatian utama dalam dalam menunjang efektivitas transfer. Bukti empiris mengenai respon pemerintah daerah untuk transfer dan pendapatan sendiri (pajak) telah banyak dibahas oleh beberapa peneliti seperti Bae dan Feiock (2004), Kusumadewi dan Rahman (2007) dan Knight (2000). Hasil analisisnya tidak berbeda. Artinya ketika penerimaan daerah berasal dari transfer, maka stimulus atas belanja yang ditimbulkannya berbeda dengan stimulus yang muncul dari pendapatan daerah (terutama pajak daerah). Ketika respon (belanja) daerah lebih besar terhadap transfer, maka disebut flypaper effect.

Tinjauan pustaka dalam penelitian ini yang akan menjadi dasar pemikiran teori adalah sebagai berikut:

Transfer. Transfer merupakan dana yang bersumber dari pendapatan APBN yang dialokasikan kepada daerah untuk mendanai kebutuhan daerah dalam rangka pelaksanaan desentralisasi. Berdasarkan konteks desentralisasi fiskal, transfer dana dari pemerintah pusat kepada pemerintah daerah merupakan hal yang tidak dapat dihindari. Desentralisasi memang merupakan pelimpahan wewenang dari pemerintah pusat kepada pemerintah daerah. Sejalan dengan desentralisasi tersebut, aspek pembiayaannya juga ikut terdesentralisasi. Implikasinya, pemerintah daerah dituntut untuk dapat membiayai sendiri biaya pembangunannya.

Pada dasarnya, transfer pemerintah pusat ke pemerintah daerah dapat dibedakan atas bagi hasil pendapatan (revenue sharing) dan bantuan (grants). Banyak literatur mengenai ekonomi publik dan keuangan publik diterangkan beberapa alasan mengapa transfer dari pemerintah pusat ke pemerintah daerah sangat diperlukan. Paling tidak ada lima alasan yang mendukung diselenggarakannya transfer dari pusat ke daerah. Kelima alasan tersebut, menurut Mulyana et. al. (2006) yaitu menjaga/menjamin tercapainya standar pelayanan publik minimum di seluruh negeri. Selain itu, tujuan transfer adalah mengurangi kesenjangan keuangan horisontal antardaerah, mengurangi kesenjangan vertikal pusat-daerah, mengatasi persoalan efek pelayanan publik antardaerah, dan untuk menciptakan stabilisasi aktifitas perekonomian di daerah. Seperti ditegaskan dalam UU No. 25 Tahun 1999, bentuk transfer yang paling penting di Indonesia adalah DAU dan DAK, selain DBH (revenue sharing).

Pengalaman empiris dari berbagai negara menunjukkan bahwa pemberian transfer oleh pemerintah pusat kepada daerah dapat disertai dengan syarat-syarat tertentu atau tidak bersyarat sama sekali. Menurut BPPK (2006) transfer dapat dikelompokkan menjadi dua kategori besar, yaitu transfer tanpa syarat (unconditional grant) dan transfer dengan syarat (conditional grant).

Transfer tanpa syarat (unconditional grant) ditujukan untuk menjamin adanya pemerataan dalam kemampuan fiskal antardaerah, sehingga setiap daerah dapat melaksanakan urusan rumah tangganya sendiri pada tingkat yang layak. Tujuan dari transfer ini adalah untuk mengurangi ketimpangan fiskal yang bersifat horisontal (horizontal equalization). Ciri utama dari transfer ini adalah daerah memiliki keleluasaan (diskresi) penuh dalam memanfaatkan dana transfer ini sesuai dengan pertimbanganpertimbangannya sendiri atau sesuai dengan aturan apa yang menjadi prioritas daerahnya.

Transfer dengan syarat digunakan untuk keperluan yang dianggap penting oleh pemerintah pusat namun kurang dianggap penting oleh daerah. Transfer ini dapat dikelompokkan ke dalam dua jenis, yaitu:

(a) Transfer pengimbang (matching grants). Transfer pengimbang adalah transfer yang diberikan oleh pusat kepada daerah untuk menutup sebagian atau seluruh kekurangan pembiayaan satu jenis urusan tertentu. Di sini pemerintah 
daerah telah mengalokasikan sejumlah dana pendapatan daerahnya untuk penyelenggaraan urusan tersebut, hanya dana tersebut belum cukup untuk menjamin penyelenggaraan urusan tersebut dengan baik. Transfer dari pemerintah pusat dalam hal ini berfungsi untuk membantu mengatasi kekurangan dana tersebut. Transfer pengimbang ini juga dapat dibedakan menjadi dua jenis, yaitu transfer pengimbang tidak terbatas (open-ended matching grants) dan transfer pengimbang terbatas (closed -ended matching grants).

(b) Transfer bukan pengimbang (non-matching grants). Transfer bukan pengimbang adalah transfer yang diberikan oleh pusat kepada daerah untuk menambah dana penyelenggaraan suatu jenis urusan tertentu tanpa mempertimbangkan bahwa pemerintah daerah sendiri akan mengalokasikan dananya dengan jumlah besar atau kecil. Jenis transfer ini oleh pemerintah pusat untuk menjadi sarana menginternalisasikan limpahan manfaat (eksternalitas) terutama kepada daerah yang menghasilkan limpahan manfaat tersebut. Jadi meskipun pemerintah daerah telah mengalokasikan pendapatan daerahnya untuk pembiayaan penyelenggaraan urusan itu, namun karena pelaksanaannya menghasilkan limpahan manfaat besar kepada daerah-daerah lain, transfer diberikan oleh pemerintah pusat untuk mendorong pemerintah daerah agar tetap bersemangat dan mau mengalokasikan pendapatan daerahnya untuk pelaksanaan fungsi tersebut.

Beberapa jenis transfer di atas, dapat dijabarkan melalui Gambar 1.

Konsep Pengeluaran Pemerintah. Pengeluaran pemerintah mencerminkan kebijakan pe- merintah. Menurut Alfirman dan Sutriaono (2006), apabila pemerintah telah menetapkan suatu kebijakan untuk membeli barang dan jasa, pengeluaran pemerintah mencerminkan biaya yang harus dikeluarkan oleh pemerintah untuk melaksanakan kebijakan tersebut. Terdapat beberapa teori yang menjelaskan tentang perkembangan pengeluaran pemerintah, sebagai berikut:

(a) Model Pembangunan tentang Perkembangan Pengeluaran Pemerintah. Model ini dikembangkan oleh Rostow dan Musgrave yang menghubungkan perkembangan pengeluaran pemerintah dengan tahap-tahap pembangunan ekonomi yaitu tahap awal, tahap menengah dan tahap lanjut.

Tahap awal perkembangan ekonomi, persentase investasi pemerintah terhadap total investasi besar sebab pada tahap ini pemerintah harus menyediakan prasarana seperti pendidikan, kesehatan, prasarana transportasi. Tahap menengah pembangunan ekonomi, investasi pemerintah tetap diperlukan untuk meningkatkan pertumbuhan ekonomi agar dapat tinggal landas, namun pada tahap ini peranan investasi swasta sudah semakin besar. Peranan pemerintah tetap besar pada tahap menengah, oleh karena peranan swasta semakin besar akan menimbulkan banyak kegagalan pasar dan juga menyebabkan pemerintah harus menyediakan barang dan jasa publik dalam jumlah yang lebih banyak. Selain itu pada tahap ini perkembangan ekonomi menyebabkan terjadinya hubungan antarsektor yang makin komplek. Misalnya pertumbuhan ekonomi yang ditimbulkan oleh perkembangan sektor industri akan menimbulkan semakin tingginya

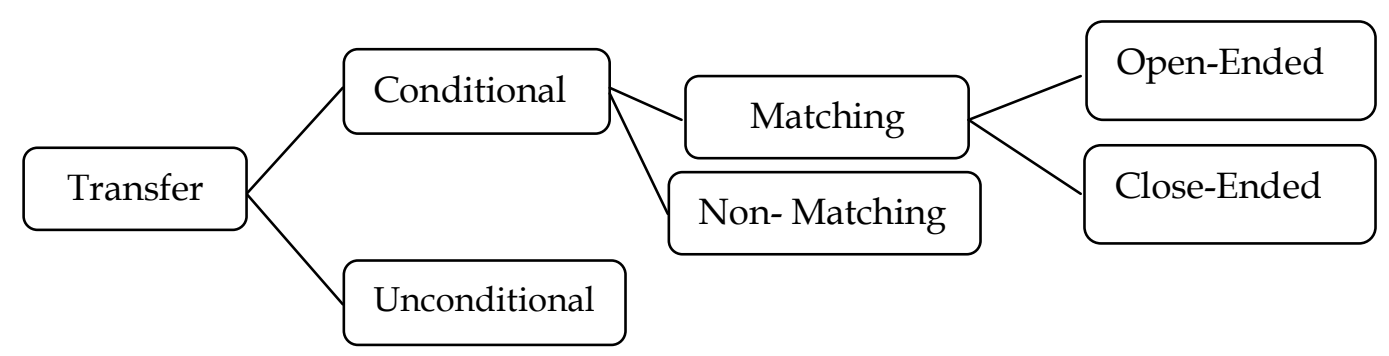

Sumber: Adams dan Maslove, 2009

Gambar 1. Klasifikasi Transfer 
pencemaran atau polusi. Pemerintah harus turun tangan mengatur dan mengurangi dampak negatif dari polusi. Pemerintah juga harus melindungi buruh dalam meningkatkan kesejahteraannya.

Alfirman dan Sutriono (2006) berpendapat bahwa dalam suatu proses pembangunan, investasi swasta dalam persentase terhadap PDB semakin besar dan persentase investasi pemerintah terhadap PDB akan semakin kecil. Tahap ekonomi lebih lanjut, Rostow mengatakan bahwa aktivitas pemerintah dalam pembangunan ekonomi beralih dari penyediaan prasarana ke pengeluaran-pengeluaran untuk aktivitas sosial seperti program kesejahteraan hari tua dan pelayanan kesehatan masyarakat.

(b) Hukum Wagner mengenai Perkembangan Aktivitas Pemerintah. Wagner mengemukakan suatu teori mengenai perkembangan pengeluaran pemerintah yang semakin besar dalam persentase terhadap PDB. Wagner mengemukakan pendapatnya bahwa dalam suatu perekonomian apabila pendapatan per kapita meningkat maka secara relatif pengeluaran pemerintah pun akan meningkat. Hukum Wagner dikenal dengan "The Law of Expanding State Expenditure". Dasar dari hukum tersebut adalah pengamatan empiris dari negara-negara maju (Amerika Serikat, Jerman, Jepang). Wagner menerangkan mengapa peranan pemerintah menjadi semakin besar, terutama disebabkan karena pemerintah harus mengatur hubungan yang timbul dalam masyarakat.

Kelemahan hukum Wagner adalah karena hukum tersebut tidak didasarkan pada suatu teori mengenai pemilihan barang-barang publik. Wagner mendasarkan pandangannya dengan suatu teori yang disebut teori organis mengenai pemerintah (organic theory of the state) yang menganggap pemerintah sebagai individu yang bebas bertindak, terlepas dari anggota masyarakat lainnya.

Teori Peacock \& Wiseman. Peacock dan Wiseman adalah dua orang yang mengemukakan teori mengenai perkembangan pengeluaran pemerintah yang terbaik. Teori mereka didasarkan pada suatu pandangan bahwa pemerintah senantiasa berusaha untuk memperbesar pengeluaran sedangkan masyarakat tidak suka membayar pajak yang semakin besar untuk membiayai pengeluaran pemerintah yang semakin besar tersebut. Teori Peacock dan Wiseman merupakan dasar teori pemungutan suara. Peacock dan Wiseman mendasarkan teori mereka pada suatu teori bahwa masyarakat mempunyai suatu tingkat toleransi pajak, yaitu suatu tingkat dimana masyarakat dapat memahami besarnya pungutan pajak yang dibutuhkan oleh pemerintah untuk membiayai pengeluaran pemerintah. Jadi masyarakat menyadari bahwa pemerintah membutuhkan dana untuk membiayai aktivitas pemerintah sehingga mereka mempunyai tingkat kesediaan masyarakat untuk membayar pajak. Tingkat toleransi ini merupakan kendala bagi pemerintah untuk menaikkan pemungutan pajak secara semenamena. Teori Peacock dan Wiseman adalah sebagai berikut:

Pertumbuhan ekonomi (PDB) menyebabkan pemungutan pajak semakin meningkat walaupun tarif pajak tidak berubah; dan meningkatnya penerimaan pajak menyebabkan pengeluaran pemerintah juga semakin meningkat. Oleh karena itu, dalam keadaan normal, meningkatnya PDB menyebabkan penerimaan pemerintah yang semakin besar, begitu juga dengan pengeluaran pemerintah menjadi semakin besar. Apabila keadaan normal tersebut terganggu, misalnya karena adanya perang, maka pemerintah harus memperbesar pengeluarannya untuk membiayai perang. Karena itu penerimaan pemerintah dari pajak juga meningkat dan pemerintah meningkatkan penerimaannya tersebut dengan cara menaikkan tarif pajak sehingga dana swasta untuk investasi dan konsumsi menjadi berkurang. Keadaan ini disebut efek pengalihan (displacement effect) yaitu adanya gangguan sosial menyebabkan aktivitas swasta dialihkan pada aktivitas pemerintah. Perang tidak hanya dibiayai dengan pajak, akan tetapi pemerintah juga melakukan pinjaman ke negara lain. Akibatnya setelah perang sebetulnya pemerintah dapat kembali menurunkan tarif pajak, namun tidak dilakukan karena pemerintah masih mempunyai kewajiban untuk mengembalikan pinjaman tersebut. Sehingga pengeluaran pemerintah meningkat karena PDB yang mulai meningkat, pe- 
ngembalian pinjaman dan aktivitas baru setelah perang. Ini yang disebut efek inspeksi (inspection effect). Adanya gangguan sosial juga akan menyebabkan terjadinya konsentrasi kegiatan ke tangan pemerintah di mana kegiatan ekonomi tersebut semula dilaksanakan untuk swasta. Ini disebut efek konsentrasi (concentration effect). Adanya ketiga efek tersebut menyebabkan aktivitas pemerintah bertambah. Setelah perang selesai dan keadaan kembali normal maka tingkat pajak akan turun kembali. Jadi berbeda dengan pandangan Wagner, perkembangan pengeluaran pemerintah versi Peacock dan Wiseman tidaklah berbentuk suatu garis, tetapi seperti tangga.

Bird mengkritik hipotesis yang dikemukakan oleh Peacock dan Wiseman. Bird menyatakan bahwa selama terjadinya gangguan sosial memang terjadi pengalihan aktivitas pemerintah dari pengeluaran sebelum gangguan ke pengeluaran yang berhubungan dengan gangguan tersebut. Hal ini akan diikuti oleh peningkatan persentase pengeluaran pemerintah terhadap PDB. Akan tetapi setelah terjadinya gangguan, persentase pengeluaran pemerintah terhadap PDB akan menurun secara perlahanlahan kembali ke keadaan semula. Jadi menurut Bird, efek pengalihan merupakan gejala dalam jangka pendek, tetapi tidak terjadi dalam jangka panjang. Satu hal yang perlu dicacat dari teori Peacock dan Wiseman adalah bahwa mereka mengemukakan adanya toleransi pajak, yaitu suatu limit perpajakan, akan tetapi mereka tidak menyatakan pada tingkat berapa toleransi pajak tersebut. Clarke menyatakan bahwa limit perpajakan adalah sebesar 25 persen dari pendapatan nasional. Apabila limit dilampaui maka akan terjadi inflasi dan gangguan lainnya.

Faktor-faktor yang menentukan Perkembangan Pengeluaran Pemerintah. Menurut Alfirman dan Sutriono (2006), perkembangan pengeluaran pemerintah ditentukan oleh beberapa faktor yaitu perubahan permintaan akan barang publik, perubahan aktivitas pemerintah dalam menghasilkan barang publik, perubahan dari kombinasi faktor produksi yang digunakan dalam proses produksi, perubahan kualitas barang publik dan perubahan harga-harga fak- tor-faktor produksi.

Lebih lanjut, Widanta (2008) mengklasifikasikan pengeluaran pemerintah menjadi lima jenis yaitu: (1) Pengeluaran yang self liquiditing sebagian atau seluruhnya, artinya pengeluaran pemerintah mendapatkan pembayaran kembali dari masyarakat yang menerima jasa atau barang bersangkutan. Misalnya pengeluaran untuk jasa perusahaan. (2) Pengeluaran yang reproduktif, artinya mewujudkan keuntungankeuntungan ekonomis bagi masyarakat, yang berpengaruh positif terhadap penerimaan pemerintah. Misalnya pengeluaran untuk pendidikan dan kesehatan. (3) Pengeluaran yang tidak self liquiditing maupun yang tidak reproduktif, yaitu pengeluaran yang langsung menambah kegembiraan dan kesejahteraan masyarakat. Misalnya obyek pariwisata. (4) Pengeluaran yang secara langsung tidak produktif dan merupakan pemborosan misalnya untuk pembiayaan pertahanan/perang meskipun saat pengeluaran terjadi penghasilan perorangannya akan naik. (5) Pengeluaran yang merupakan penghematan di masa yang akan datang. Misalnya pengeluaran untuk anak yatim piatu. Jika hal ini tidak dijalankan sekarang kebutuhan pemeliharaan tersebut akan menjadi lebih besar di masa yang akan datang.

Klasifikasi pengeluaran pemerintah yang digunakan baik pemerintah pusat maupun daerah terdiri dari dua pengeluaran: (1). Pengeluaran/belanja rutin adalah belanja untuk pemeliharaan atau penyelanggaraan pemerintah sehari-hari. Pengeluaran rutin ini merupakan perkembangan istilah yang bersumber pada ICW (Indische Comptabiliteit-Wet Staatsblad 1923 Nomor 448) belanja rutin ini terdiri dari belanja pegawai, belanja barang, belanja pemeliharaan dan belanja perjalanan. (2) Belanja pembangunan adalah pengeluaran untuk pembangunan baik pembangunan fisik seperti jalan, jembatan, gedung, maupun pembangunan non fisik spiritual termasuk penataran, training.

Hubungan Unconditional Grants (DAU dan DBH) dengan Belanja Daerah. Darwanto dan Yulia (2007) menyatakan terdapat keterkaitan sangat erat antara transfer dari pemerintah pusat dengan belanja pemerintah daerah. Secara spesifik mereka menegaskan bahwa variabel-variabel kebijakan pemda dalam jangka 
pendek disesuaikan (adjusted) dengan transfer yang diterima, sehingga memungkinkan terjadinya respon yang non-linier dan asymmetric.

Lebih lanjut Maimunah (2006) menyatakan bahwa telah terjadi flypaper effect dalam merespon belanja teransfer DAU dan PAD di Pulau Sumatera, sedangkan Deller et al. (2007) menganalisis hubungan pendapatan yang berasal dari bagi hasil dengan menggunakan suatu model perilaku keuangan lokal dengan menggunakan data 581 kota dan desa di Wisconsin, Amerika Serikat dan menemukan untuk setiap dollar kenaikan dalam pendapatan daerah, maka pengeluaran daerah meningkat sekitar 12 sampai 15 sen. Untuk setiap kenaikan dalam pendapatan bagi hasil (revenue sharing), peningkatan pengeluaran daerah mencapai 46-55 sen. Deller et al. (2007) menduga bahwa pola respon daerah ini juga dipengaruhi oleh formula penentuan bagi hasil itu sendiri. Hasil ini konsisten dengan hipotesis flypaper effect.

Hubungan PAD dengan Belanja Daerah. Prakosa (2004) dan Ashworth et al. (2005) menyatakan bahwa tingkat pendapatan akan memiliki pengaruh positif pada pengeluaran publik. Sementara sebagian lainnya menyatakan bahwa belanjalah yang mempengaruhi pendapatan (Maimunah, 2006). Hipotesis yang menyatakan bahwa pendapatan daerah (terutama pajak) akan mempengaruhi anggaran belanja pemerintah daerah dikenal dengan nama taxspend hypothesis (Maimunah dan Akbar, 2008). Dalam hal ini, pengeluaran pemerintah daerah akan disesuaikan dengan perubahan dalam penerimaan pemerintah daerah atau perubahan pendapatan terjadi sebelum perubahan pengeluaran.

Hubungan PDRB dengan Belanja Daerah. Peningkatan PDRB akan berdampak pada peningkatan kegiatan ekonomi, utamanya di sektor riil dan dunia usaha pada umumnya. Peningkatan kegiatan ekonomi akan membawa pengaruh meningkatkan penerimaan pemerintah melalui perpajakan, karena bergairahnya perekonomian sehingga aktivitas dunia usaha meningkat dan pada akhirnya keuntungan perusahaan meningkat pula. Peningkatan aktivitas dan keuntungan perusahaan ini tentunya akan meningkatkan pemungutan pajak baik dari pajak penghasilan, pertambahan nilai maupun cukai. Jika penerimaan pemerintah meningkat, maka akan membawa konsekuensi peningkatan pengeluaran pemerintah.

Secara teori, semakin besar Produk Domestik Regional Bruto (PDRB), maka akan semakin besar pula pendapatan yang diterima oleh kabupaten/kota. Dengan semakin besar pendapatan yang diperoleh daerah, maka pengalokasian belanja oleh pemerintah daerah akan lebih besar untuk meningkatkan berbagai potensi lokal di daerah tersebut untuk kepentingan pelayanan publik (Darwanto dan Yulia, 2007).

Flypaper Effect. Flypaper effect merupakan suatu kondisi dimana stimulus terhadap pengeluaran daerah yang disebabkan oleh adanya perubahan dalam jumlah transfer (unconditional grants) dari pemerintah pusat lebih besar dari yang disebabkan oleh perubahan dalam pendapatan daerah. Hal tersebut merupakan fenomena utama dalam penelitian ini, dimana flypaper effect disebut sebagai suatu kondisi yang terjadi saat pemerintah daerah merespon (belanja) lebih banyak dengan menggunakan dana transfer daripada menggunakan kemampuan (pendapatan) sendiri. Istilah flypaper effect dikembangkan oleh Dollery and Worthington (1995) yang menyatakan bahwa pemerintah daerah menggunakan pendapatan transfer (grants) untuk memperluas belanja publik daripada pendapatan daerah (lokal), baik secara langsung melalui rabat atau tidak langsung melalui dikurangi pajak. Implikasinya berkaitan dengan alasan politik dan birokratis, yaitu transfer (grants) untuk pemerintah daerah cenderung mengarah pada pengeluaran daerah lebih besar daripada pendapatan daerah (Shah, 2006). Penjelasan dari dampak ini disebutkan bahwa para birokrat berusaha untuk memaksimalkan anggaran karena dengan melakukan hal tersebut akan membuat mereka memiliki kekuatan dan pengaruh yang lebih besar di masyarakat (Shah, 2009).

Dalam hal ini, transfer tanpa syarat menggunakan formula yang biasa digunakan. Transfer federal dan negara bagian pada penduduk di Brazil merupakan contoh grants dalam bentuk ini. Bukti-bukti temuan menyarankan bahwa bentuk transfer akan mendorong penduduk untuk memperendah basis pajak mereka sendiri (Shah, 2009). 
Beberapa literatur ekonomi dan keuangan daerah yang berkaitan dengan dengan pengertian flypaper effect (misalnya Aller, 2007; Hindriks dan Myles 2006; Inman, 2008; Lalvani, 2006; dan Schoeman, 2011) menemukan bahwa stimulus terhadap pengeluaran daerah yang disebabkan transfer (grants) mengalami kenaikan yang lebih besar daripada pendapatan daerah. Hal tersebut sejalan dengan oleh Aragon (2008) yang menyatakan flypaper effect merupakan stimulus terhadap pengeluaran daerah yang disebabkan unconditional grants lebih besar daripada pendapatan daerah. Atau definisi yang lain menyatakan bahwa flypaper effect adalah respon pemerintah daerah berbeda untuk transfer dan pendapatan daerahnya sendiri. Ketika respon pemerintah daerah lebih besar untuk transfer dibanding pendapatan daerahnya sendiri maka disebut flypaper effect (Sukriy dan Halim, 2003).

Beberapa studi empiris berikutnya kemudian menunjukkan bahwa perbedaan stimulus antara grants dan pendapatan sendiri memang terjadi dibeberapa negara. Misalnya Dahlberg et al, 2006; Guadarrama, 2006; Legrenzi dan Milas, 2001; Nilsson, 2009; Rios dan Jose, 2005; Sour dan Giron, 2009.

Dahlberg et. al. (2006) menemukan bukti empiris flypaper effect di Swedia. Ia menemukan pengeluaran daerah yang disebabkan transfer (grants) mengalami kenaikan yang lebih besar daripada pendapatan daerah. Ini terjadi karena transfer (grants) untuk pemerintah daerah cenderung lebih besar mengarah pada pengeluaran daerah, namun tidak untuk pajak (penurunan).

Penelitian Legrenzi dan Milas (2001) juga memberikan bukti empiris tentang adanya flypaper effect dalam jangka panjang untuk sampel municipalities di Italia. Mereka menyatakan bahwa local governments consistently increase their expenditure more with respect to increase in State transfer rather than to increase in own revenues. Secara empiris juga ditemukan adanya flypaper effect dalam municipalities di Finlandia (Nilsson, 2009). Ia menemukan adanya kenaikan pengeluaran daerah yang disebabkan grant yang lebih besar daripada pendapatannya. Menurutnya orang akan lebih hemat dalam membelanjakan pendapatan yang merupakan hasil dari effortnya sendiri dibanding pendapatan yang diberikan pihak lain dalam bentuk grants (Syukriy dan Halim, 2006).

Rios dan Jose (2005) menemukan bukti flypaper effect dalam municipalities di Portugal. Ia menemukan bahwa kenaikan unconditional grants mendorong pengeluaran pemerintah lokal lebih besar daripada hasil (pendapatan) masyarakat setempat. Guadarrama (2006) dan Sour dan Giron (2009) menemukan bukti flypaper effect dalam municipalities di Meksiko. Ia menemukan adanya kenaikan pengeluaran daerah yang disebabkan transfer tanpa syarat (unconditional grant) yang lebih besar daripada pendapatannya.

Lebih lanjut, studi empiris mengenai perbedaan stimulus antara grants dan pendapatan sendiri ditemukan juga di Indonesia (Kuncoro, 2004; Kusuma dan Rahman, 2007; Sudrajat, 2010; dan Widarjono, 2006). Kuncoro (2004) mendukung adanya flypaper effect dalam kabupaten/kota di Indonesia. Ia menunjukkan bahwa transfer (grants) antar pemerintah merangsang peningkatan pengeluaran pemerintah daerah lebih besar daripada pendapatan daerahnya.

Hal tersebut tersebut sejalan dengan Kusuma dan Rahman (2007) yang menyatakan bahwa pengaruh pengaruh transfer (grants) terhadap belanja daerah lebih signifikan dibandingkan pengaruh pendapatan daerah terhadap belanja daerah yang berarti terjadi flypaper effect pada seluruh kabupaten/kota di Indonesia. Sudrajat (2010) memberikan bukti empiris mengenai pengaruh transfer (grant) dan pendapatan daerah terhadap belanja daerah pada kabupaten/kota di Provinsi Lampung. Penelitiannya menunjukkan bahwa pengaruh transfer (grants) terhadap belanja daerah lebih signifikan dibandingkan pengaruh pendapatan daerah terhadap belanja daerah. Hasil ini menunjukkan adanya flypaper effect.

Kemudian Widarjono (2006) menemukan adanya flypaper effect pada wilayah barat dan timur di Indonesia. Ia menunjukkan bahwa flypaper effect yang terjadi di daerah timur (Kalimantan, Sulawesi, Bali, Nusa Tenggara, dan Pulau Irian) lebih besar daripada daerah barat (Sumatera dan Jawa). Temuan ini menunjukkan pengaruh transfer (grants) terhadap belanja daerah lebih signifikan dibandingkan pengaruh 
pendapatan daerah terhadap belanja daerah.

Fenomena flypaper effect membawa implikasi lebih luas bahwa transfer akan meningkatkan belanja pemerintah daerah yang lebih besar daripada penerimaan transfer itu sendiri. Fenomena flypaper effect dapat terjadi menurut Kuncoro (2007) dan Mendes (2005) apabila pada elastisitas pengeluaran terhadap transfer yang lebih tinggi daripada elastisitas pengeluaran terhadap penerimaan pajak daerah.

Berdasarkan latar belakang, rumusan masalah, kajian teori, dan penelitian sebelumnya maka dirumuskan hipotesis sebagai berikut: pertama, diduga unconditional grants (DAU dan DBH), PAD dan PDRB berpengaruh positif terhadap peningkatan belanja daerah di provinsi Jawa Barat. Kedua, pengaruh unconditional grants (DAU dan DBH) terhadap belanja daerah lebih besar daripada pengaruh pendapatan asli daerah terhadap belanja daerah di provinsi Jawa Barat.

\section{METODE PENELITIAN}

\section{Metode dan Data}

Metode dasar yang digunakan dalam penelitian ini adalah metode eksplanasi yaitu berusaha menjelaskan hubungan satu variabel dengan variabel yang lain, dengan menyoroti hubungan yang telah dirumuskan sebelumnya (Nazir, 2003). Penelitian ini menggunakan satu variabel terikat (dependen) yaitu belanja daerah dan tiga variabel bebas (independen) yaitu unconditional grants, pendapatan asli daerah dan PDRB.

Penelitian menggunakan data populasi, di mana populasi, yaitu seluruh daerah kabupaten/kota di provinsi Jawa Barat. Penelitian ini dilakukan secara sensus dengan data sekunder berbentuk time series dari tahun 2004 sampai dengan 2008, dan data cross section yang terdiri atas 25 kabupaten/kota, sehingga merupakan pooled the data yaitu gabungan antara data time series (tahun 2004-2008: 5 tahun) dengan data cross section 25 kabupaten/kota. Data diperoleh dari Badan Pusat Statistik (BPS), Bappeda, dan instansi terkait lainnya.

Metode penelitian ini menggunakan teknik pengambilan non-probability sampling dengan cara purposive sampling yaitu teknik penentuan sampel dengan pertimbangan tertentu. Adapun pertimbangan yang ditentukan dalam pengambilan dalam pengambilan sampel adalah sebagai berikut: pertama, pemerintahan kabupaten/ kota di provinsi Jawa Barat yang telah menyerahkan laporan realisasi APBDnya ke Badan Pusat Statistik provinsi Jawa Barat, dan melalui situs Departemen Keuangan Dirjen Perimbangan Keuangan Pusat dan Daerah (www.djpk. depkeu. go.id). Kedua, pemerintahan kabupaten/kota yang terdapat di Provinsi Jawa Barat memiliki informasi keuangan yang dibutuhkan dalam penelitian ini sebagai variabel penelitian. Informasi tersebut antara lain belanja daerah, pendapatan asli daerah, dana alokasi umum, dana bagi hasil dan PDRB seacara berturutturut mulai tahun 2004-2008.

Berdasarkan pertimbangan yang telah disebutkan di atas, maka dari 25 sampel, ada 6 kabupaten/kota yang tidak memiliki laporan realisasi APBD berturut-turut mulai tahun 2004-2008. Dengan demikian, sampel akhir yang digunakan dalam penelitian ini sejumlah 13 pemerintahan kabupaten dan 6 pemerintahan kota, yaitu kabupaten Bandung, kabupaten Bekasi, kabupaten Bogor, kabupaten Ciamis, kabupaten Cianjur, kabupaten Cirebon, kabupaten Indramayu, kabupaten Karawang, kabupaten Majalengka, kabupaten Purwakarta, kabupaten Subang, kabupaten Sumedang, kabupaten Tasikmalaya, kota Bandung, kota Bekasi, kota Bogor, kota Depok, kota Cimahi, dan kota Banjar.

\section{Metode Analisis}

Model yang digunakan untuk menganalisis flypaper effect mengikuti penelitian sebelumnya seperti Maimunah (2006), Darwanto dan Yustikasari (2007) serta Rios dan Jose (2005). Fungsi yang digunakan dalam persamaan ini:

$B D_{i t}=f\left(\mathrm{UG}_{\mathrm{it}}, \mathrm{PAD}_{\mathrm{it}}, \mathrm{PDRB}_{\mathrm{it}}\right)$

Model di atas kemudian dispesifikasikan dalam bentuk model sebagai berikut:

$\mathrm{BD}_{\mathrm{it}}=\mathrm{b}_{\mathrm{o}}+\mathrm{b}_{1} \mathrm{UG}_{\mathrm{it}}+\mathrm{b}_{2} \mathrm{PAD}_{\mathrm{it}}+\mathrm{b}_{3} \mathrm{PDRB}_{\mathrm{it}}+\mu_{\mathrm{it}}(2)$ 
Tabel 1. Bukti Empiris Terjadinya Flypaper Effect

\begin{tabular}{|c|c|c|c|c|}
\hline No & Nama penulis & Sampel & $\begin{array}{c}\text { Bagi Hasil } \\
\text { Pendapatan/Bantuan }\left(\beta_{1}\right)\end{array}$ & $\begin{array}{c}\text { Pendapatan daerah } \\
\left(\beta_{2}\right)\end{array}$ \\
\hline 1. & $\begin{array}{l}\text { Gramlich and } \\
\text { Galper (1973) }\end{array}$ & $\begin{array}{l}10 \text { US urban goverment, } \\
1962-1970\end{array}$ & 0,25 & 0,05 \\
\hline 2. & $\begin{array}{l}\text { Gramlich and } \\
\text { Galper (1973) }\end{array}$ & $\begin{array}{l}\text { aggregat US state and } \\
\text { local government data } \\
\text { (quarterly), 1954-1972 }\end{array}$ & 0,43 & 0,10 \\
\hline 4. & $\begin{array}{l}\text { Case, Hines and } \\
\text { Rosen (1993) }\end{array}$ & 48 US state, $1970-1985$ & 0,65 to 1,02 & 0,11 to 0,17 \\
\hline 5. & $\begin{array}{l}\text { Gamkhar and } \\
\text { Oates (1996) }\end{array}$ & $\begin{array}{l}\text { aggregate US state and } \\
\text { local government data } \\
\text { (annual), 1953-1991 }\end{array}$ & 0,62 to 0,73 & 0,11 to 0,28 \\
\hline 6. & Heyndels (2001) & $\begin{array}{l}308 \text { flemish } \\
\text { municipalities, 1989-1996 }\end{array}$ & 1,03 to 1,13 & 0,04 to 0,05 \\
\hline 7. & $\begin{array}{l}\text { Gemmel, } \\
\text { Morrissey, Pinar } \\
(2002)\end{array}$ & $\begin{array}{l}54 \text { english and welsh } \\
\text { countries, 1991/1992 and } \\
\text { 1993/1994 }\end{array}$ & 0,70 to 0,75 & 0,10 to 0,22 \\
\hline 8. & $\begin{array}{l}\text { Tovmo and Falch } \\
(2002)\end{array}$ & $\begin{array}{l}605 \text { Norwegian rural } \\
\text { municipalities, } \\
\text { 1934/1935 }\end{array}$ & 1,31 to 2,09 & 0,07 to 0,10 \\
\hline 9. & $\begin{array}{l}\text { Levaggi and } \\
\text { Zanola (2003) }\end{array}$ & $\begin{array}{l}18 \text { Italian regions, 1989- } \\
1993\end{array}$ & 0,56 to 0,84 & 0,01 to 0,02 \\
\hline
\end{tabular}

Sumber: Gennari and Messina, 2009

dimana BD adalah belanja daerah, UG adalah dana alokasi umum dan dana bagi hasil, PAD adalah pendapatan asli daerah, PDRB adalah Produk Domestik Regional Bruto, i adalah cross section, $\mathrm{t}$ adalah time series, $\mu$ adalah Error term, $b_{o}$ adalah konstanta, $b_{1}, b_{2}$, dan $b_{3}$ adalah koefisien regresi.

Deteksi terhadap flypaper effect dapat diperoleh melalui pertama, nilai koefisien transfer (unconditional grants) lebih besar dari nilai koefisien pendapatan daerah (PAD) dan keduanya signifikan, atau kedua, pendapatan daerah (PAD) tidak signifikan (Khairani, 2008; Maimunah, 2006, serta Sagbas dan Saruc, 2004).

\section{HASIL DAN PEMBAHASAN}

\section{Pengujian Model}

Menurut Widarjono (2009), setidaknya ada tiga teknik analisis dalam menggunakan data panel yaitu common effect, fixed effect model, dan random effect model. Untuk memilih model yang tepat dari ketiga teknik analisis tersebut, maka perlu dilakukan beberapa pengujian, yaitu F Test, Uji Hausman, serta Uji Lagrange Multiplier (LM). Uji Lagrange Multiplier (LM) perlu dilakukan dilakukan apabila hasil $\mathrm{F}$ test menunjukkan Common Effect sebagai model yang sesuai sementara Uji Hausman menunjukkan bahwa Random Effect sebagai model yang sesuai, sehingga perlu dibandingkan antara kedua model melalui uji LM.

\section{Uji Chow-test (Pool vs Fixed effect)}

Pengujian $F$ test digunakan untuk membandingkan antara Common Effect dengan Fixed Effect Model sebagai model yang paling cocok untuk analisis data panel. Adapun kaidah keputusan dalam pengujian $\mathrm{F}$ test adalah sebagai berikut:

$\mathrm{H}_{0}$ : Common Effect atau Pool Effect Model

$\mathrm{H}_{1}$ : Fixed Effect Model

Berdasarkan hasil analisis dapat dilihat 
bahwa nilai $\mathrm{F}$ test dan Chi Square pada belanja daerah sebesar 0,911293 dan 19,256290 dengan probabilitas sebesar 0,5676 dan 0,3762 atau lebih besar dari $a=5 \%$, sehingga kita menerima $\mathrm{H}_{0}$ dan menyimpulkan bahwa Common Effect atau Pool Effect Model sebagai teknik analisis yang lebih sesuai. Secara lengkap hasil F Test disajikan dalam Tabel 2.

Tabel 2. Hasil Pengujian untuk Menentukan Common Effect Model dengan Fixed Effect Model Melalui F Test

Redundant fixed effect tests

Pool:PLS

Test cross-section fixed effect

\begin{tabular}{llll}
\hline Effect Test & Statistic & d.f. & Prob. \\
\hline Cross-section F & 0,911293 & $(18,73)$ & 0,5676 \\
$\begin{array}{l}\text { Cross-section Chi- } \\
\text { square }\end{array}$ & 19,256290 & 18 & 0,3762 \\
\hline
\end{tabular}

Sumber: Hasil pengolahan data, Eviews 7

Berdasarkan hasil Uji Chow-test dapat disimpulkan bahwa Common Effect atau Pool Effect Model merupakan teknik analisis yang paling sesuai untuk digunakan dalam analisis data panel ini.

\section{Uji Lagrange Multiplier (LM)}

Pengujian LM test digunakan untuk membandingkan antara Common Effect dengan Random Effect Model sebagai model yang paling cocok untuk analisis data panel. Adapun kaidah keputusan dalam pengujian LM test adalah sebagai berikut: $\mathrm{H}_{0}$ adalah Common Effect atau Pool Effect Model sedangkan $\mathrm{H}_{1}$ adalah Random Effect Model.

Berdasarkan hasil analisis dapat dilihat bahwa nilai $\mathrm{F}$ test dan Chi Square pada belanja daerah sebesar 1,791293 dan 3,676131 dengan probabilitas sebesar 0,1727 dan 0,1591 atau lebih besar dari $\alpha=5 \%$, sehingga kita menerima $\mathrm{H}_{0}$ dan menyimpulkan bahwa Common Effect atau Pool Effect Model sebagai teknik analisis yang lebih sesuai. Secara lengkap hasil LM Test disajikan dalam Tabel 3.

Berdasarkan hasil F test dan LM test dapat disimpulkan bahwa Common Effect atau Pool
Effect Model merupakan teknik analisis yang paling sesuai untuk digunakan dalam analisis data panel ini. Dengan demikian hausman test, yaitu pengujian untuk memilih antara Random Effect Model dengan Fixed Effect Model menjadi tidak diperlukan lagi.

Tabel 3. Hasil Pengujian untuk Menentukan Common Effect Model dengan Random Effect Model Melalui LM

Breusch-Godfrey Serial Correlation LM Test:

\begin{tabular}{llll}
\hline F-statistic & 1,791293 & Prob. & 0,1727 \\
Obs*R- & 3,676131 & $\mathrm{~F}(2,89)$ & 0,1591 \\
squared & & Prob. Chi- \\
& & Square (2) \\
\hline
\end{tabular}

Sumber: Hasil pengolahan data, Eviews 7

\section{Pengujian Asumsi Klasik}

Normalitas. Berdasarkan hasil pengujian asumsi klasik menggunakan Eviews 7, diperoleh nilai Jarque-Bera sebesar sebesar 1190,071 dengan probabilitas sebesar 0,0000 . Nilai probabilitas Jarque-Bera lebih kecil dari alpha 0,05, sehingga kita menolak $\mathrm{H}_{0}$ dan menyimpulkan bahwa error term tidak terdistribusi normal. Lebih jelasnya dapat dilihat pada Gambar 2.

Multikolinearitas. Masalah multikolinearitas dapat dideteksi dengan melihat nilai koefisien determinasi $\left(\mathrm{R}^{2}\right)$ regresi model utama dibandingkan dengan nilai $\mathrm{R}^{2}$ regresi parsialnya atau dikenal dengan istilah korelasi parsial (examination of partial correlation). Bila didapati nilai $\mathrm{R}^{2}$ regresi model utama lebih besar daripada nilai $\mathrm{R}^{2}$ regresi parsialnya, maka dikatakan model yang diteliti tidak terkena masalah multikolinearitas. Tabel 4 menunjukkan nilai $\mathrm{R}^{2}$ hasil regresi parsial untuk masing-masing persamaan.

Tabel 4. Koefisien Determinasi $\left(\mathbf{R}^{2}\right)$ Parsial Persamaan BD

\begin{tabular}{cccc}
\hline \multirow{2}{*}{ BD } & \multicolumn{3}{c}{$\begin{array}{c}\text { Regresi Parsial Variabel } \\
\text { Independen }\end{array}$} \\
\cline { 2 - 4 } & UG & PAD & PDRB \\
\hline $\mathrm{R}^{2}=0,9298$ & $\mathrm{R}^{2}=0,4092$ & $\mathrm{R}^{2}=0,6617$ & $\mathrm{R}^{2}=0,6052$ \\
\hline
\end{tabular}

Sumber: Hasil pengolahan data, Eviews 7 


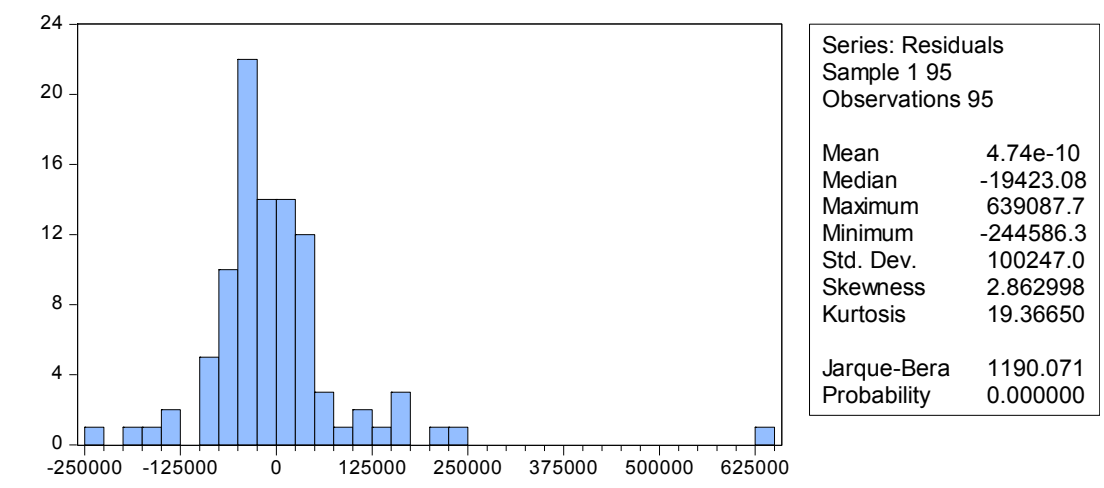

Sumber: Hasil pengolahan data, Eviews 7

Gambar 2. Hasil Pengujian Normalitas Melalui Jarque - Bera Test

Dari rangkuman di atas, dapat dilihat bahwa nilai regresi $R^{2}$ pada persamaan regresi utama BD lebih besar dari nilai $\mathrm{R}^{2}$ pada regresi parsial variabel independen $B D\left(R^{2}=0,9298\right)$, yaitu UG $\left(\mathrm{R}^{2}=0,4092\right)$, PAD $\left(\mathrm{R}^{2}=0,6617\right)$, dan PDRB $\left(R^{2}=0,6052\right)$. Artinya, model estimasi regresi $\mathrm{BD}$ tidak terkena gejala multikolinearitas.

Autokorelasi. Autokorelasi dalam konsep regresi berarti komponen error atau residual berkorelasi berdasarkan urutan waktu (pada data time series) atau urutan ruang (pada data cross section). Untuk mendapatkan hasil yang baik, seharusnya model terbebas dari persoalan autokorelasi Pengujian asumsi autokorelasi dilakukan dengan menggunakan statistik Durbin Watson (DW).

Winarno (2009) berpendapat nilai $d$ akan berada di kisaran 0 hingga 4 seperti Tabel 5 .

Tabel 5. Tabel untuk Menentukan Ada Tidaknya Autokorelasi dengan Durbin Watson

\begin{tabular}{|c|c|c|c|c|}
\hline $\begin{array}{l}\text { Tolak } \\
\mathrm{H}_{0} \text {, ber- } \\
\text { arti ada } \\
\text { autokore } \\
\text { lasi posi- } \\
\text { tif }\end{array}$ & $\begin{array}{l}\text { Tidak } \\
\text { dapat } \\
\text { diputus } \\
\text { kan }\end{array}$ & $\begin{array}{l}\text { Tidak } \\
\text { menolak } \\
\mathrm{H}_{0} \text {, ber- } \\
\text { arti ti- } \\
\text { dak ada } \\
\text { autokore } \\
\text { lasi }\end{array}$ & $\begin{array}{l}\text { Tidak } \\
\text { dapat } \\
\text { diputus } \\
\text { kan }\end{array}$ & $\begin{array}{l}\text { Tolak } \\
\mathrm{H}_{0}, \text { ber- } \\
\text { arti ada } \\
\text { autoko- } \\
\text { relasi } \\
\text { negatif }\end{array}$ \\
\hline 0 & & $\begin{array}{c}1 \\
2 \\
2,46\end{array}$ & $\mathrm{~d}_{2,90} 4$ & 4 \\
\hline
\end{tabular}

Sumber: Winarno, 2009
Berdasarkan hasil analisis data diperoleh nilai Durbin Watson sebesar 1,813. Berdasarkan tabel Durbin Watson, maka nilai $d$ berada di antara 1,54 dan 2,46. Dengan demikian nilai Durbin Watson yang dihasilkan terletak pada kaidah keputusan untuk menolak adanya autokorelasi.

Heteroskedastisitas. Heteroskedastisitas merupakan kondisi di mana varian (o2) dari faktor penggangu atau error term (disturbance term) adalah tidak sama untuk semua observasi atau pengamatan atas variabel bebas (Xi). Untuk melihat apakah terdapat heteroskedastisitas daam model akan digunakan white test. Adapun kaidah keputusannya adalah sebagai berikut: $H_{0}$ adalah residual bersifat homoskedastisitas, sedangkan $H_{1}$ adalah residual bersifat heteroskedastisitas

Berdasarkan hasil analisis residual menggunakan software Eviews, diperoleh White test sebesar 0,540916 dengan probabilitas 0,9098. Dengan demikian nilai probabilitas white test lebih besar dari nilai $a=5 \%$, sehingga menerima $\mathrm{H}_{0}$ dan menyimpulkan bahwa terdapat homoskedastisitas dalam model. Secara jelas hasil pengujian heteroskedastisitas disajikan dalam Tabel 6 .

\section{Hasil Estimasi Pengaruh Unconditional Grants, Pendapatan Asli Daerah dan PDRB terhadap Belanja Daerah}

Penelitian dilakukan studi emprik dengan analisis data yang diperoleh dari sumber data (dili- 
Tabel 6. Hasil Pengujian Heterokedastisitas Melalui White Test

Heteroskedasticity Test: White

\begin{tabular}{llll}
\hline F-Statistic & 0,173703 & Prob. F(14,80) & 0,9139 \\
Obs*R-squared & 0,540916 & Prob. Chi-Square(14) & 0,9098 \\
Scaled explained SS & 4,557868 & Prob. Chi-Square(14) & 0,2072 \\
\hline
\end{tabular}

Sumber: Hasil pengolahan data, Eviews 7

hat pada Tabel 7). Analisis yang akan dilakukan adalah pengaruh variabel-variabel yang berkaitan dengan faktor-faktor yang mempengaruhi belanja daerah pada 19 kabupaten/ kota di Provinsi Jawa Barat. Adapun hasil dari analisis tersebut ditampilkan dalam Tabel 7.

Berdasarkan hasil analisa data diperoleh nilai $t$ hitung variabel UG sebesar 23,56967 dengan probabilitas sebesar 0,0000 . Artinya probabilitas yang diperoleh lebih kecil daripada $\alpha=5 \%(0,0000<0,05)$, sehingga kita dapat menolak hipotesis nol $\left(\mathrm{H}_{0}\right)$ dan menyimpulkan bahwa UG berpengaruh positif dan signifikan terhadap belanja daerah. Sementara itu, nilai $t$ hitung varibel PAD adalah sebesar 5,055004 dengan probabilitas 0,0000 . Artinya nilai probabilitas lebih kecil dari $\alpha=5 \%(0,0000<0,05)$, sehingga kita dapat menolak $\mathrm{H}_{0}$ dan menyimpulkan bahwa PAD berpengaruh positif dan signifikan terhadap belanja daerah.

Namun, nilai t hitung variabel PDRB sebesar -2,126002 dengan probabilitas 0,0362. Artinya nilai probabilitas lebih kecil dari $\alpha=5 \%$ $(0,0362<0,05)$, sehingga kita dapat menolak $\mathrm{H}_{0}$ dan menyimpulkan bahwa PDRB berpengaruh negatif dan signifikan terhadap belanja daerah.

Penentuan flypaper effect dapat dilakukan dengan membandingkan dua koefisien variabel independen yaitu UG dan PAD. Hasil analisa data menunjukkan tidak terjadinya flypaper effect karena koefisien PAD lebih besar daripada UG dan kedua-duanya signifikan $\beta_{2}=1,18>\beta_{1}=1,10$.

\section{Analisis Pengaruh Unconditional Grants, Pendapatan Asli Daerah dan PDRB terhadap Belanja Daerah}

Pengaruh Unconditional Grants terhadap Belanja Daerah. Berdasarkan hasil estimasi antara unconditional grants terhadap belanja daerah di kabupaten/kota provinsi Jawa Barat, menunjukkan bahwa unconditional grants berpengaruh positif dan signifikan terhadap belanja daerah. Hasil studi ini mendukung temuan empiris Maimunah (2006), Darwanto dan Yulia (2007) dan Deller et al (2007).

Hal ini disebabkan karena unconditional grants merupakan bentuk transfer yang paling penting selain dana alokasi khusus. Transfer merupakan konsekuensi dari tidak meratanya kemampuan keuangan dan ekonomi daerah.

Tabel 7. Estimasi Model Pooled Least Square Cross-Section Weights

\begin{tabular}{lccc}
\hline Variabel dependen: & Belanja Daerah & & \\
\hline Variabel Independen & Koefisien & t-Statistik & Prob. \\
UG & 1,106059 & 23,56967 & 0,0000 \\
PAD & 1,186933 & 5,055004 & 0,0000 \\
PDRB & $-3,375263$ & $-2,126002$ & 0,0362 \\
\hline $\mathrm{R}^{2}=0,929809$ & & & \\
\hline Adjusted R ${ }^{2}=0,927495$ & & & \\
\hline F-Stat $=401,8187$ & & \\
\hline * Signifikan pada level 5\%
\end{tabular}

Sumber : Hasil pengolahan data, eviews 7 
Tujuan dana transfer adalah untuk mengurangi kesenjangan keuangan dan untuk menciptakan stabilisasi aktifitas perekonomian di daerah. Unconditional grants merupakan dana yang berasal dari APBN, yang dialokasikan dengan tujuan pemerataan kemampuan keuangan antar daerah untuk membiayai kebutuhan pengeluarannya dalam rangka pelaksanaan desentralisasi.

Berdasarkan Tabel 8, dapat dilihat bahwa terjadi fluktuasi kontribusi unconditional grants terhadap belanja daerah. Melihat data bahwa sebagian besar daerah memiliki persentase kontribusi antara 82,42-74,78 persen terhadap belanja daerahnya, hal ini berarti belanja daerah dibiayai oleh 82,42-74,78 persen dari dana dana perimbangan. Berdasarkan pada hal tersebut, sangat jelas terlihat bahwa daerah di Jawa Barat masih mengalami ketergantungan secara keuangan yang sangat tinggi pada pemerintah pusat.

Pengaruh Pendapatan Asli Daerah terhadap Belanja Daerah. Berdasarkan hasil estimasi antara pendapatan asli daerah terhadap belanja daerah di kabupaten/kota provinsi Ja- wa Barat, menunjukkan bahwa PAD berpengaruh positif dan signifikan terhadap belanja daerah. Hasil studi ini mendukung temuan empiris Prakosa (2004), Ashworth et al (2005), Maimunah (2006), Maimunah dan Akbar (2008).

Hal ini disebabkan PAD adalah penerimaan yang diperoleh dari sumber-sumber dalam wilayahnya sendiri yang dipungut berdasarkan peraturan daerah sesuai dengan perundang-undangan yang berlaku. Semakin besar nilai PAD maka semakin besar pula stimulus untuk meningkatkan belanja daerah. Kemandirian dalam APBD sangat terkait dengan kemandirian pemerintah daerah dalam menggali potensi PAD yang merupakan pendapatan yang berasal dari potensi daerah. Target PAD yang ditetapkan oleh pemerintah daerah didasarkan pada potensi daerah dan realisasi PAD pada tahun sebelumnya. Sehingga semakin besar realisasi pendapatan yang diperoleh dari PAD maka semakin besar pula dana yang harus disalurkan pemerintah daerah melalui pengalokasian anggaran belanja daerah untuk tahun selanjutnya.

Kuncoro (2007) berpendapat juga bahwa

Tabel 8. Kontribusi Unconditional Grants terhadap Belanja Daerah

\begin{tabular}{clrrrrr}
\hline \multirow{2}{*}{ No } & \multirow{2}{*}{ kabupaten/Kota } & \multicolumn{3}{c}{ Persentase Kontribusi } \\
\cline { 3 - 6 } & & $\mathbf{2 0 0 4}$ & $\mathbf{2 0 0 5}$ & $\mathbf{2 0 0 6}$ & $\mathbf{2 0 0 7}$ & $\mathbf{2 0 0 8}$ \\
\hline 1 & Kab. Bandung & 81,82 & 79,48 & 89,13 & 87,40 & 78,28 \\
2 & Kab. Bekasi & 73,06 & 79,60 & 63,75 & 70,58 & 97,08 \\
3 & Kab. Bogor & 81,99 & 75,45 & 73,44 & 79,06 & 76,87 \\
4 & Kab. Ciamis & 88,02 & 84,40 & 98,22 & 71,81 & 69,85 \\
5 & Kab. Cianjur & 84,64 & 83,73 & 88,32 & 79,73 & 74,14 \\
6 & Kab. Cirebon & 81,10 & 81,76 & 79,39 & 78,42 & 75,67 \\
7 & Kab. Indramayu & 78,61 & 85,17 & 89,55 & 81,91 & 81,15 \\
8 & Kab. Karawang & 81,25 & 82,82 & 76,09 & 78,99 & 74,71 \\
9 & Kab. Majalengka & 81,91 & 82,65 & 85,99 & 9,59 & 77,09 \\
10 & Kab. Purwakarta & 73,59 & 74,50 & 77,88 & 75,98 & 74,63 \\
11 & Kab. Subang & 117,76 & 84,84 & 86,25 & 76,71 & 71,70 \\
12 & Kab. Sumedang & 76,66 & 71,85 & 80,36 & 76,44 & 72,88 \\
13 & Kab. Tasikmalaya & 85,97 & 85,65 & 90,35 & 81,94 & 88,97 \\
14 & Kota. Bandung & 84,64 & 62,68 & 67,26 & 70,09 & 65,68 \\
15 & Kota. Bekasi & 84,72 & 77,53 & 81,29 & 67,87 & 63,16 \\
16 & Kota. Bogor & 73,25 & 73,37 & 75,41 & 77,13 & 76,58 \\
17 & Kota. Depok & 70,98 & 72,79 & 78,18 & 69,93 & 66,33 \\
18 & Kota. Cimahi & 88,05 & 76,44 & 83,47 & 71,71 & 69,93 \\
19 & Kota. Banjar & 77,90 & 68,58 & 84,39 & 86,63 & 66,18 \\
\hline
\end{tabular}

Sumber: Departemen Keuangan Dirjen Perimbangan Keuangan Pusat dan Daerah (www.djpk.depkeu.go.id), data diolah. 
kenaikan dalam pajak akan meningkatkan belanja daerah sehingga akhirnya akan memperbesar defisit. Ini juga disebabkan karena pendapatan asli daerah atau juga pajak adalah penerimaan yang diperoleh daerah dari sumber-sumber dalam wilayahnya sendiri yang dipungut berdasarkan peraturan daerah sesuai dengan perundang-undangan yang berlaku. Sumber pendapatan asli daerah berasal dari sektor pajak daerah, retribusi daerah, hasil pengelolaan kekayaan daerah yang dipisahkan dan pendapatan lain-lain yang sah (Mardiasmo, 2002).

Pengaruh PDRB terhadap Belanja Daerah. PDRB dan pendapatan asli daerah (PAD) memiliki hubungan secara fungsional, karena PDRB merupakan fungsi dari PAD (Purbayu, 2005). Semakin tinggi PDRB perkapita suatu daerah, maka semakin besar pula potensi sumber penerimaan daerah tersebut (Thamrin, 2001). Selanjutnya dengan peningkatan penerimaan daerah, akan digunakan untuk membiayai program-program pembangunan daerah. Karena peningkatan dari penerimaan daerah akan meningkatkan PDRB. Jadi, PDRB dan belanja daerah memiliki hubungan yang positif. Bila PDRB mengalami peningkatan maka belanja daerah juga akan mengalami peningkatan.

Berdasarkan hasil estimasi antara PDRB terhadap belanja daerah di kabupaten/kota provinsi Jawa Barat, menunjukkan bahwa PDRB berpengaruh negatif dan signifikan terhadap belanja daerah. Hasil studi ini tidak mendukung penelitian sebelumnya oleh Prakosa (2004), Ashworth et al (2005), Maimunah (2006), Maimunah dan Akbar (2008).

PDRB berpengaruh negatif terhadap belanja daerah karena PAD lebih banyak digunakan untuk membiayai belanja tidak langsung (rutin) daripada untuk membiayai belanja langsung (publik), sehingga berdampak pada sektor-sektor publik seperti sektor industri, sektor perdagangan, sektor perikanan mengalami penurunan produksi. Temuan ini sejalan dengan hasil studi Darwanto dan Yulia (2007).

Lebih lanjut, Nugroho et al. (2010) berpendapat tinggi/rendahnya PDRB bukan hanya ditentukan oleh belanja tidak langsung dan belanja langsung. Karena berdasarkan studi empiris diperoleh bahwa belanja tidak langsung dan belanja langsung hanya sebesar 52-54 persen saja. Artinya ada faktor-faktor lain yang tidak terdeteksi sebesar 46-48 persen yang mempengaruhi tinggi/rendahnya PDRB di Jawa Barat.

Flypaper effect. Flypaper effect merupakan suatu kondisi dimana stimulus terhadap pengeluaran daerah yang disebabkan oleh adanya perubahan dalam jumlah transfer (unconditional grants) dari pemerintah pusat lebih besar dari yang disebabkan oleh perubahan dalam pendapatan daerah. Hal ini tentu bertentangan asas desentralisasi dan prinsip otonomi di mana pemerintah daerah dituntut untuk lebih mandiri tanpa bergantung pada pemerintah pusat.

Hasil studi penelitian yang dilakukan di 19 kabupaten/kota di provinsi Jawa Barat, ditemukan fakta bahwa kapasitas fiskal daerah memiliki pengaruh yang lebih dominan terhadap belanja daerah daripada pengaruh dana alokasi umum terhadap belanja daerah. Hasil penelitian ini menunjukkan bahwa tidak terjadi flypaper effect pada belanja daerah, pemerintahan daerah di provinsi Jawa Barat telah mandiri dari segi keuangan karena telah mampu bertumpu pada kemampuan keuangan daerah itu sendiri dalam menjalankan roda pemerintahan. Hal ini dimungkinkan mengingat potensi yang cukup besar yang ada di daerah Jawa Barat. Posisi yang strategis dan kaya akan sumber daya alam menjanjikan sumber-sumber penerimaan yang besar, baik itu pajak dan retribusi daerah maupun pemanfaatan sumber daya alam serta pajak melalui dana bagi hasil.

\section{SIMPULAN}

Berdasarkan analisis hasil studi dan pembahasan tentang faktor-faktor yang mempengaruhi belanja daerah di kabupaten/kota provinsi Jawa Barat, dapat ditarik simpulan sebagai berikut: Pertama, Unconditional grants berpengaruh signifikan dan mempunyai hubungan yang positif terhadap belanja daerah di Jawa Barat. Kedua, pendapatan asli daerah berpengaruh signifikan dan mempunyai hubungan yang positif terhadap belanja daerah di Jawa Barat. Ketiga, PDRB berpengaruh signifikan dan mempunyai hubungan yang negatif terhadap belanja daerah di Jawa Barat. Keempat, Nilai koefisien penda- 
patan asli daerah (PAD) lebih besar dari unconditional grants dan keduanya signifikan. Ini menunjukan tidak terjadinya flypaper effect di Jawa Barat.

Berdasarkan kesimpulan yang dihasilkan dalam studi ini, maka disampaikan beberapa saran yang diharapkan berguna untuk kepentingan praktis dan penelitiaan selanjutnya, yaitu: Pertama, diharapkan untuk penelitian selanjutnya agar memperbanyak jumlah sampel kabupaten/kota, khususnya di luar Provinsi Jawa Barat. Hal ini bertujuan agar semakin banyak diketahui daerah mana saja yang sudah mandiri maupun yang belum mandiri. Kedua, bagi pemerintah daerah yang bersangkutan. Hasil penelitian ini menunjukkan prestasi pemerintahan kabupaten/kota dalam pembiayaan yang lebih bertumpu pada kemampuan daerah (kapasitas fiskal) itu sendiri. Namun di sisi lain, peran pemerintah pusat melalui unconditional grants masih cukup besar sehingga pemerintah daerah harus lebih berupaya mengurangi peran unconditional grants. Ketiga, Mengingat tingginya ketergantungan pemerintah daerah terhadap besarnya transfer unconditional grants maka untuk mengurangi ketergantungan terhadap pemerintah pusat, pemerintah daerah harus mengupayakan untuk memaksimalkan potensi daerahnya yang akan berdampak pada meningkatnya PAD seperti mendorong kinerja industri manufaktur, agroindustri, jasa, dan sektor ekonomi lainnya yang potensial dikembangkan. Keempat, pemerintah daerah juga perlu meningkatkan peningkatan pendapatan asli daerah meliputi: (1) intensifikasi dan ekstensifikasi pungutan daerah dalam bentuk retribusi atau pajak; (2) eksplorasi sumber daya alam; dan (3) skema pembentukan kapital (capital formation) atau investasi daerah melalui penggalangan dana atau menarik investor.

\section{DAFTAR PUSTAKA}

Abdullah, Sukriy dan Abdul Halim. 2003. Pengaruh Dana Alokasi Umum (DAU) dan Pendapatan Asli Daerah (PAD) terhadap Belanja Pemerintah Daerah Studi Kasus kabupaten/Kota di Jawa dan Bali. Simpo- sium Nasional Akuntansi VI, Yogyakarta, Hal. 1140-1159.

Abdullah, Sukriy dan Abdul Halim. 2006. Studi atas Belanja Modal pada Anggaran Pemerintah Daerah dalam Hubungannya dengan Belanja Pemeliharaan dan Sumber Pendapatan. Jurnal Akuntansi Pemerintah, Vol. 2, No.2, November 2006, Hal 17-32.

Adams, Erika dan Allan Maslove. 2009. Innovations in Transfer Payments to Local Governments: the Case of the Gas Tax Fund. Submitted to the Workshop on: Cities and Multilevel Governance - American and Canadian Perspectives: the Federal Government and Multilevel Governance in Canada Canadian Political Science Association 81th Conference May 27th-28th 2009 Centre for Urban Research and Education (CURE) School of Public Policy and Administration Carleton University Ottawa, Canada.

Alfirman, L. 2003. Estimating Stochastic Frontier Tax Potential: Can Indonesian Local Governments Increase Tax Revenues under Decentralization?. Working Paper No. 03-19, Department of Economic, University of Colorado at Bolder, Colorado.

Alfirman, Luky dan Edy Sutriono. 2006. Analisis Hubungan Pengeluaran Pemerintah dan Produk Domestik Bruto dengan Menggunakan Pendekatan Granger Causality dan Vector Autoregression. Jurnal Keuangan Publik, Vol. 4, No. 1, April 2006 Hal 25 - 66.

Allers, Maarten. 2007. Deriving Spending Needs from Local Government Budget Data: Methodological Problems and a Proposed Solution. University of Groningen Preliminary version - September 2007.

Aragon, Fernando M. 2008. The Flypaper Effect Revisited. STICERD, London School of Economics, November 2008.

Ashworth, J., Geys, B. \& Heyndels, B. (2005). Government Weakness and Local Public Debt Development in Flemish Municipal- 
ities. International Tax and Public Finance, 12, 395-422.

Badan Pendidikan dan Pelatihan Keuangan (BPPK). 2006. Buku Keuangan Publik: Teori dan Aplikasi. Jakarta: Lembaga Pengkajian Keuangan Publik dan Akuntansi Pemerintah (LPKPAP).

Bae, San-Seok dan Richard C. Feiock. 2004. The Flypaper Effect Revisited: Intergovernmental Grants and Local Governance. International Journal of Public Administration, Vol. 27, Nos. 8 \& 9, pp. 577-596.

Bastida, Francisco, Bernardino Benito dan $\mathrm{M}^{\mathrm{a}}$ Dolores Guillamon. 2010. An Assessment of Local Government Spending in Spain. Dpto. de Economía Financiera y ContabilidadFacultad de Economía y Empresa, Universidad de Murcia.

Brodjonegoro, B. 2001. Indonesian Intergovernmental Transfer in Decentralization Era: the case of general allocation fund. Paper disajikan dalam International Symposium on Intergovernmental Transfers in Asian Countries, 9-10 Februari 2001.

Brojonegoro, Bambang dan Jorge MartinezVazquez. 2002. An Analysis of Indonesia's transfer system: Recent Performance and Future Prospects. Working Paper 02-13, May. Andrew Young School of Policy Studies, Georgia State University.

Boadway, Robin dan Anwar Shah. 2009. Fiscal Federalism: Principles and Practices of Multorder Governance. Published in the United States of America by Cambridge University Press, New York

Dahlberg, M., Mork, E., Rattso, J. dan Agren, H. (2006). Using a discontinuous grant rule to identify the effect of grants on local taxes and spending. Working Paper No. 25. Sweden, Uppsala University, Department of Economics. Available at http://www. nek.uu.se/Pdf/wp2006_25.pdf. Access date: 10 June 2009.
Darwanto dan Yulia Yustikasari. 2007. Pengaruh Pertumbuhan Ekonomi, Pendapatan Asli Daerah, dan Dana Alokasi Umum terhadap Pengalokasian Anggaran Belanja Modal. Simposium Nasional Akuntansi $X$, UNHAS Makasar, 26-28 Juli 2007.

Deller, Steven, Craig S Maher, dan Victor Lledo. 2007. Wisconsin Local Government, State Share Revenue and the Illusive Flypaper Effect. J. of Public Budgeting, Accounting dan Financial Management, 19 (2), 200-220, Summer 2007.

Dollery, Brian dan Andrew Worthington. 1995. Federal Expenditure and Fiscal Illusion: A Test of the Flypaper Hypothesis in Australia. Publius, Vol. 25, No. 1, pp. 23-34.

Fitrani, F., Hofman, B., dan Kaiser, K. 2005. Unity in Diversity? The Creation of New Local Governments in a Decentralising Indonesia. Bulletin of Indonesian Economic Studies, LXI(1): 57-79.

Fane, G.2003. Change and Continuity in Indonesia's New Fiscal Decentralisation Arrangements. Bulletin of Indonesian Economic Studies, XXXIX(1):159-76.

Gennari, Elena and Messina, Giovanna. 2009. The Relevance of the Flypaper Effect Through Municipal Data. Bank of Italy, Preliminary version, September, 2009.

Guadarrama, Cesar Velazquez. 2006. Determinantes del gasto estatal en Mexico. Gestión y Poitica Publica, Volumen XV, Numero 1, I Semestre de 2006, PP. 83-109

Hindriks, Jean dan Myles Gareth D. 2006. Intermediate Public Economics. The MIT Press Cambridge, Massachusetts London, England.

Inman, Robert. P. 2008. The Flypaper Effect. NBER Working Paper No. 14579, December- 2008

Khairani, Siti. 2008. Pengaruh Dana Alokasi Umum (DAU) dan Pendapatan Asli Daerah (PAD) terhadap Belanja Aparatur dan Belanja Pelayanan Publik pada Pemerin- 
tah Daerah (Studi Empiris kabupaten/ Kota di Provinsi Sumatera Selatan dan Bangka Belitung). Kajian Ekonomi, Vol. 7 No. 1, 2008: 54-75.

Knight, Brian. 2002. The Flypaper Effect Unstuck: Evidence on Endogenous Grants from the Federal Highway Aid Program. Division of Research and Statistics, Board of Governors of the Federal Reserve System Washington, DC.

Kuncoro, Haryo. 2004. Pengaruh Transfer antar Pemerintah pada Kinerja Fiskal Pemerintah Daerah Kota dan kabupaten di Indonesia. Jurnal Ekonomi Pembangunan, Vol. 9 No. 1, Juni 2004, Hal. 47 - 63.

Kuncoro, Haryo. 2007. Fenomena Flypaper Effect pada Kinerja Keuangan Pemerintah Daerah Kota dan kabupaten di Indonesia. Simposium Nasional Akuntansi X, UNHAS Makasar, 26-28 Juli 2007.

Kusumadewi, Diah Ayu dan Arief Rahman. 2007. Flypaper Effect pada Dana Alokasi Umum (DAU) dan Pendapatan Asli Daerah (PAD) terhadap Belanja Daerah pada kabupaten/Kota di Indonesia. JAAI, Vol. 11 No. 1.

Lalvani, M. (2002). The Flypaper Effect: Evidence from India. Public Budgeting and Finance, 22, 67-88.

Legrenzi. Gabriella \& Costas Milas. 2001. Nonlinier and Asymetrics Adjustment in the Local Revenue-Expenditure Models: some Evidence from the Italian Municipalities. University of Milan, Working paper.

Maimunah, Mutiara dan Akbar, Rusdi. 2008. Flypaper Effect pada Dana Alokasi Umum (DAU) dan Pendapatan Asli Daerah (PAD) terhadap Belanja Daerah pada kabupaten/Kota di pulau Sumatera. Jurnal Riset Akuntansi Indonesia, Vol. 1 I, No. 1, Januari 2008,Hal. 37-51

Maimunah, Mutiara 2006. Flypaper Effect pada Dana Alokasi Umum (DAU) dan Pendapatan Asli Daerah (PAD) terhadap Belan- ja Daerah pada kabupaten/Kota di pulau Sumatera. Simposium Nasional Akuntansi IX, Padang, 2006.

Mardiasmo, 2002. Otonomi dan Manajemen Keuangan Daerah. Yogyakarta: Andi.

Mello Jr., L.R.D. dan M. Barenstrein, 2001. Fiscal Decentralization and Governance: A CrossCountry Analysis. IMF, Washington, DC.

Mendes, Marcos. 2005. Capture of Fiscal Transfers: A Study of Brazilian Local Governments. Econ. Aplic., 9(3): 427-444, jul-set 2005

Mulyana, Budi, Subkhan dan Kuwat slamet. 2006. Keuangan Daerah-Perspektif Desentralisasi Fiskal dan Pengelolaan APDB di Indonesia. Jakarta: Lembaga Pengkajian Keuangan Publik dan Akuntansi Pemerintah (LPKPAP).

Nazir, Mohammad. 2003. Metode Penelitian,. Jakarta: Ghalia Indonesia.

Nilsson, Helene L. 2009. How Local are Local Governments? Heterogeneous Effects of Intergovernmental Grants. Department of Economics Uppsala University, Working paper 2009:16 November 2009.

Nugroho, Eko., Irzan, Achmad., Chalamsa, Miftah., Juwarto., Wijaya, Dastam. 2010. Hubungan Pola Belanja dengan PDRB: Pelatihan Analisis Data Keuangan Daerah 2010. Jakarta: Lembaga Penyelidikan Ekonomi dan Masayarakat - FEUI.

Prakosa, Kesit Bambang. 2004. Analisis Pengaruh Dana Alokasi Umum (DAU) dan Pendapatan Asli Daerah (PAD) Terhadap Prediksi Belanja Daerah (studi empiric di wilayah Provinsi Jawa Tengah dan DIY). JAAI, Vol. 8. No. 2, 2004.

Purbayu, Budi Santosa. 2005. .Analisis Pendapatan Asli Daerah (PAD) dan FaktorFaktor Yang Mempengaruhinya dalam Upaya Pelaksanaan Otonomi Daerah di kabupaten Kediri. Jurnal Dinamika Pembangunan, Vol.2, No.1, Ilmu Ekonomi 
Studi Pembangunan Fakultas Ekonomi Universitas Diponegoro, Semarang.

Rios, Maria Emilia dan Jose da Silva Costa. 2005. O Efeito Flypaper nas Transferencias para os Municipios Portugueses, Revista Portuguesa de Estudos Regionais, $\mathrm{n}^{\circ} 8,1^{\circ}$ Quadrimestre, 2005.

Sagbas, Isa dan Naci Tolga Saruç. 2004. Intergovernmental Transfers and the Flypaper Effect in Turkey. Turkish Studies, Vol. 5, No. 2, Summer 2004, pp.79-92.

Schoeman, Niek. 2011. Fiscal Performance and Sustainability of Local Government in South Africa - An Empirical Analysis. Working paper 201, University of Pretoria, Department of Economics.

Shah, Anwar. 2006. A Practitioner's Guide to Intergovernmental Fiscal Transfers. World Bank Policy Research Working Paper 4039, October 2006

Simanjuntak, Robert A. 2000. Implikasi Fiskal Pelaksanaan Otonomi Daerah. Usahawan, No. 4 April.

Halim, Abdul (ed). 2001. Bunga Rampai Manajemen Keuangan Daerah. Yogyakarta: Unit Penerbit dan Percetakan (UPP) AMP YKPN.

Sour, Lauran dan Fredy Giron. 2009. Electoral Competition and the Flypaper Effect in Mexican Local Governments. Division de Administracion Publica, Centro de Económicas y Docencia Investigacion, carretera México, www.cide.edu.

Sudrajat. 2010. Fenomena Flypaper Effect pada kabupaten/Kota di Provinsi Lampung. Jurnal ESAI, Vol. 4 No. 3 Juli 2010.

Tadjoeddin, Zulfan M., Suharyo, W.I. dan Mishra, S. 2001. Regional Disparity and Vertical Conflict in Indonesia. UNDP/ UNSFIR (United National Special Facility for Indonesian Recovery), Mimeo, Jakarta.

Wibowo, Puji. 2008. Mencermati Dampak Desentralisasi Fiskal terhadap Pertumbuhan Ekonomi Daerah. Jurnal Keuangan Publik, Vol. 5 No. 1, Oktober.

Widarjono, Agus. 2006. Does Intergovernmental Transfers Cause Flypaper Effect on Local Spending?. Jurnal Ekonomi Pembangunan, Kajian Ekonomi Negara Berkembang, Hal. 115 - 123.

Widanta, A.A.B. 2008. Peranan Pembiayaan Pembangunan dan Investasi dalam Pembangunan Daerah. Input Jurnal Ekonomi dan Sosial, No. 2, Agustus 2008.

Widarjono, Agus. 2009. Ekonometrika: Pengantar dan Aplikasinya (Dilengkapi Aplikasi Eviews). Yogyakarta: Penerbit EKONISIA.

Winarno, Wahyu. 2009. Analisis Ekonometrika dan Statistika dengan EViews, Edisi kedua. Yogyakarta: Penerbit UPP STIM KPN. 